\title{
Space-temporal dynamics of limnological variables in a floodplain wetland located at Ribeira do Iguape Valley (São Paulo, Brazil) at different hydrological periods
}

Dinâmica espaço-temporal de variáveis limnológicas em uma área alagada localizada no Vale do Ribeira do Iguape (São Paulo, Brasil) em diferentes períodos hidrológicos

Roseli Frederigi Benassi ${ }^{1}$, Rogério Herlon Furtado Freire ${ }^{2}$ and Maria do Carmo Calijuri ${ }^{3}$

${ }^{1}$ Centro de Engenharia, Modelagem e Ciências Sociais Aplicadas, Universidade Federal do ABC - UFABC, Santo André, SP, Brazil e-mail: roseli.benassi@ufabc.edu.br

${ }^{2}$ Programa de Pós-graduação em Energia, Universidade Federal do ABC - UFABC, Santo André, SP, Brazil e-mail: rogerioherlon@gmail.com

${ }^{3}$ Escola de Engenharia de São Carlos - EESC, Universidade de São Paulo - USP, São Carlos, SP, Brazil e-mail: calijuri@sc.usp.br

\begin{abstract}
Aim: The main goal of this research was to investigate the influence of the hydrological pulses on the space-temporal dynamics of physical and chemical variables in a wetland adjacent to Jacupiranguinha River (São Paulo, Brazil); Methods: Eleven sampling points were distributed among the wetland, a tributary by its left side and the adjacent river. Four samplings were carried out, covering the rainy and the dry periods. Measures of $\mathrm{pH}$, dissolved oxygen, electrical conductivity and redox potential were taken in regular intervals of the water column using a multiparametric probe. Water samples were collected for the nitrogen and total phosphorus analysis, as well as their dissolved fractions (dissolved inorganic phosphorus, total dissolved phosphorus, ammoniacal nitrogen and nitrate). Total alkalinity and suspended solids were also quantified; Results: The Multivariate Analysis of Variance showed the influence of the seasonality on the variability of the investigated variables, while the Principal Component Analysis gave rise in two statistical significant axes, which delimited two groups representative of the rainy and dry periods. Hydrological pulses from Jacupiranguinha River, besides contributing to the inputs of nutrients and sediments during the period of connectivity, accounted for the decrease in spatial gradients in the wetland. This "homogenization effect" was evidenced by the Cluster Analysis. The research also showed an industrial raw effluent as the main point source of phosphorus to the Jacupiranguinha River and, indirectly, to the wetland; Conclusions: Therefore, considering the scarcity of information about the wetlands in the study area, this research, besides contributing to the understanding of the influence of hydrological pulses on the investigated environmental variables, showed the need for adoption of conservation policies of these ecosystems face the increase anthropic pressures that they have been submitted, which may result in lack of their ecological, social and economic functions.
\end{abstract}

Keywords: tropical wetland, flood pulses, connectivity, dry and rainy periods, space-temporal variability.

Resumo: Objetivo: $\mathrm{O}$ objetivo desta pesquisa foi investigar a influência dos pulsos de inundação sobre a dinâmica espaço-temporal de variáveis físicas e químicas em uma área alagada adjacente ao Rio Jacupiranguinha (São Paulo, Brasil). Onze pontos de amostragem foram distribuídos entre a área alagada, incluindo um tributário pela margem esquerda e o canal do rio adjacente; Métodos: Quatro campanhas de amostragem foram realizadas, cobrindo os períodos seco e chuvoso. Medidas de $\mathrm{pH}$, oxigênio dissolvido, condutividade elétrica e potencial redox foram realizadas em intervalos regulares da coluna d'água usando uma sonda multiparâmetros. Amostras de água foram coletadas para análise de nitrogênio e fósforo total, além de suas fraçôes dissolvidas (fósforo inorgânico dissolvido, fósforo total dissolvido, nitrogênio amoniacal e nitrato). Alcalinidade total e sólidos suspensos também foram quantificados; Resultados: A Análise Multivariada de Variância mostrou influência da sazonalidade sobre a variabilidade das variáveis investigadas, enquanto que a Análise de Componentes Principais deu origem a dois eixos estatisticamente significativos, os quais delimitaram dois grupos representativos dos períodos seco e chuvoso. Os pulsos 
hidrológicos do Rio Jacupiranguinha, além de contribuírem para o aporte de nutrientes e sedimentos durante o período de conectividade, foram responsáveis pela diminuição dos gradientes espaciais na área alagada. Este "efeito de homogeneizaçáo" foi evidenciado pela Análise de Cluster. A pesquisa também mostrou um efluente bruto industrial como a principal fonte pontual de fósforo para o Rio Jacupiranguinha e, indiretamente, para a área alagada; Conclusóes: Portanto, considerando a escassez de informaçôes sobre os ecossistemas aquáticos da área de estudo, esta pesquisa, além de contribuir para o entendimento da influência dos pulsos hidrológicos sobre as variáveis ambientais da área alagada investigada, mostrou a necessidade da adoção de medidas de conservação destes ecossistemas frente à crescente pressão antrópica a que estão submetidos, as quais podem resultar em perdas de suas funçóes ecológicas, sociais e econômicas.

Palavras-chave: área alagada tropical, pulsos de inundação, conectividade, períodos seco e chuvoso, variabilidade espaço-temporal.

\section{Introduction}

Floodplain wetlands are characterized as highly dynamic systems, where the space-temporal dynamics of environmental variables and the structure of biological communities are primarily conditioned by the annual hydrological regime of the adjacent rivers (Junk et al., 1989; Neiff, 1990, 2001; Henry, 2003). Flood pulses are admittedly the main factor in determining the extension of connectivity between wetlands and natural channels in floodplains, contributing decisively to the establishment of noticeable environmental gradients, besides inputting matter and energy, which have direct implications on the ecology of wetlands (Junk et al., 1989; Junk, 1997; Thomaz et al., 1997; Neiff, 1999; Tundisi, 2007). In addition to the environmental reset promoted by floods, the input of nutrients from the bottom sediments and decomposing vegetation contributes significantly to the high productivity usually observed in natural wetlands (Junk and Welcomme, 1990; Carvalho et al., 2001; Benassi, 2006). Considering that wetlands are among the most important yet vulnerable ecosystems on the planet and that alterations in land use within their catchment area have strongly contributed to the degradation and destruction of their buffering capacity, with profound ecological, social and economic repercussions (Kansiime et al., 2007; Mitsch et al., 2009; Rebelo et al., 2010), studies carried out in order to understand the functioning and the role these ecosystems become an important tool to highlight their functions and to support the development of policies and management actions at local, regional and global levels (Whitaker et al., 1995; Rebelo et al., 2010). In our research, we chose a floodplain wetland never studied before, located at the Ribeira do Iguape Valley (São Paulo, Brazil). Although locating in two very developed Brazilian's states (Paraná e São Paulo) and having the Mata Atlântica Tropical Forest as an important environmental patrimony, the natural richness of the Ribeira do Iguape Valley contrasts with several social and economic problems, including high illiteracy rates and low coverage of the sanitation services (Calijuri et al., 2008). In consequence, local aquatic ecosystems have been submitted to heavy loads of pollutants from industrial, agricultural and domestic sources. Therefore, besides contributing with the state of knowledge concerning local aquatic ecosystems, which have been scarcity studied, the main goal of this research was to investigate the influence of hydrological pulses on the space-temporal variability of physical and chemical variables in a wetland adjacent to Jacupiranguinha River (Ribeira do Iguape Valley, São Paulo, Brazil).

\subsection{Study area}

The Ribeira do Iguape Basin is located between $23^{\circ} 30^{\prime}-25^{\circ} 30^{\prime}$ south and $46^{\circ} 50^{\prime}-50^{\circ} 00^{\prime}$ west, covering an area of $28,306 \mathrm{~km}^{2}, 61 \%$ of which is situated in the São Paulo State and 39\% in the Paraná State (Brazil). The basin has a prolongated conformation on SW-NE direction, closely paralleled to the ocean front (Figure 1). At this geographical region, the Jacupiranguinha River, a meandric system characterized by a large zone of low declivity submitted to seasonal flood pulses in periods of intense precipitation, presents natural wetlands adjacent to its main channel, which have never been studied before. According to Moccellin (2006), there is a significant lack of the original vegetation on the riversides, which was partially substituted by banana and tea cultivation. 
The main urban nucleus of the Jacupiranguinha River sub basin is the Cajati city, which has an estimated population of 29,227 inhabitants (SABESP, 2005) and an economy based on the production of sulfuric acid and phosphochemicals derived from apatite, which are used in production of fertilizers, animal food and cement. The industrial chemical complex situated in Cajati is responsible for the greatest national production of sulfuric acid. However, it must be stressed that agriculture, especially banana cropping, is a relevant activity for the local economy.

Stabilization ponds have been considered the most economically viable alternative for wastewater treatment in Ribeira do Iguape Basin, even though their effluents may cause significant inputs of nitrogen and phosphorus to the receiver water bodies (Calijuri et al., 2008).

Of the total of domestic effluents produced by the city of Cajati, $67 \%$ are collected and $90 \%$ are subsequently treated by a stabilization pond system (Australian configuration), before being directly discharged into the Jacupiranguinha River at a point upstream of the investigated wetland.

The surrounding wetland's landscape is characterized by areas of pasture and banana cropping, as well as native vegetation. The climate of the studied area, according to Köppen classification, is Cfa type - humid subtropical with hot summers. The most of precipitation occurs between November and April, with the highest Jacupiranguinha River's flows currently observed during January-February (Benassi, 2006).

\section{Material and Methods}

\subsection{Sampling points}

Samplings were carried out in January and April/05, months representative of the rainy period, and in October/04 and July/05, both occurring in the dry period. Only during the sampling carried out in January/05 was a complete connectivity between the Jacupiranguinha River and the wetland observed.

The sampled points were distributed among the Jacupiranguinha River (two points), the wetland (six points), including a channel that drains the wetland (two points), and the Serrana stream (one point), a wetland tributary by the left side (Figure 2). The Table 1 shows the geographical localization and some environmental characteristics of the chosen points.

\subsection{Topography}

To delimite the wetland area, as well as to relate the Jacupiranguinha River's levels with the degree of connectivity among these systems, a topographic study using a teodolihte MOM BUDAPESTE ${ }^{\oplus}$ model TE-D43 was performed.

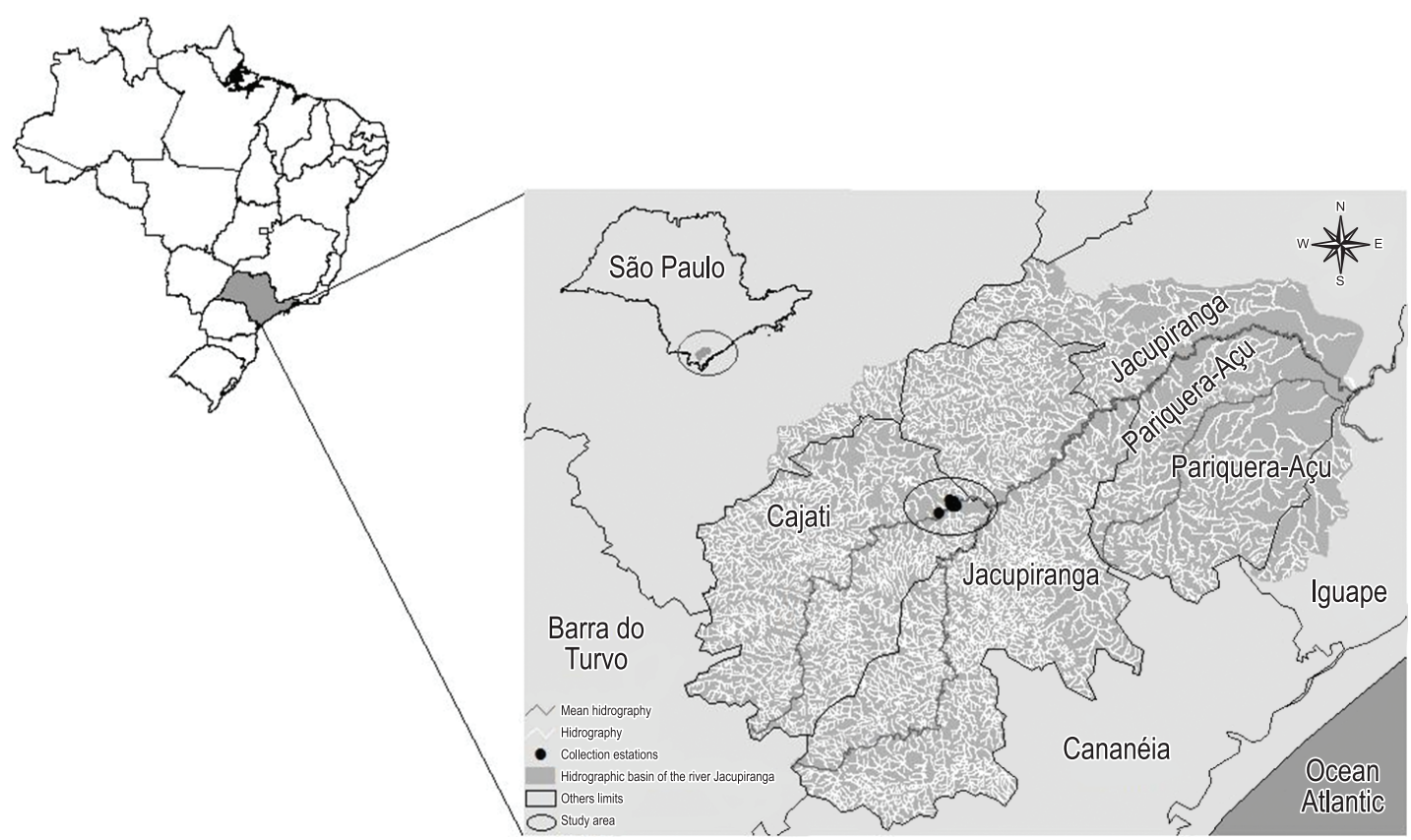

Figure 1. Geographical location of the study area, highlighting the Jacupiranguinha River's microbasin and an overview of the sampling points. 
Table 1. Geographical localization and environmental characteristics of the sampling points.

\begin{tabular}{|c|c|}
\hline Point/Geographical localization & Environmental aspects \\
\hline 1 (S 24 43' 22" and WO 48 05' 37") & $\begin{array}{l}\text { At the Jacupiranguinha River, approximately } 30 \mathrm{~m} \text { downstream from } \\
\text { stabilization ponds' discharges }\end{array}$ \\
\hline 2 (S $24^{\circ} 43^{\prime} 35^{\prime \prime}$ and WO $\left.48^{\circ} 04^{\prime} 54^{\prime \prime}\right)$ & $\begin{array}{l}\text { At the Jacupiranguinha River, approximately } 300 \mathrm{~m} \text { downstream from } \\
\text { industrial plant's discharges and } 1,000 \mathrm{~m} \text { from the stabilization ponds } \\
\text { system }\end{array}$ \\
\hline 3 (S $24^{\circ} 42^{\prime} 43^{\prime \prime}$ and WO $\left.48^{\circ} 05^{\prime} 06^{\prime \prime}\right)$ & $\begin{array}{l}\text { At the Serrana stream, a wetland's tributary by the left side strongly } \\
\text { influenced by grassland areas }\end{array}$ \\
\hline 4 (S $24^{\circ} 42^{\prime} 55^{\prime \prime}$ and WO $\left.48^{\circ} 04^{\prime} 59^{\prime \prime}\right)$ & $\begin{array}{l}\text { The first point of connectivity between the wetland and the Jacupiranguinha } \\
\text { River when overflow begins. Characterized by high density of Pistia } \\
\text { stratiotes, Azolla spp. and Brachiaria spp. }\end{array}$ \\
\hline 5 (S $24^{\circ} 42^{\prime} 53^{\prime \prime}$ and WO $\left.48^{\circ} 04^{\prime} 59^{\prime \prime}\right)$ & Point with environmental characteristics similar to the point 4 \\
\hline 6 (S $24^{\circ} 42^{\prime} 55^{\prime \prime}$ and WO $\left.48^{\circ} 04^{\prime} 59^{\prime \prime}\right)$ & $\begin{array}{l}\text { Point directly influenced by inflows from Serrana stream, with high densities } \\
\text { of Eichhornia crassipes, Azolla spp. and Pistia stratiotes }\end{array}$ \\
\hline 7 (S $24^{\circ} 42^{\prime} 47^{\prime \prime}$ and WO $\left.48^{\circ} 04^{\prime} 53^{\prime \prime}\right)$ & $\begin{array}{l}\text { Besides Eichhornia azurea and Pistia stratiotes, this point presented high } \\
\text { density of Nymphaea spp. }\end{array}$ \\
\hline $\begin{array}{l}\left.8 \text { (S } 24^{\circ} 42^{\prime} 47^{\prime \prime} \text { and WO } 48^{\circ} 04^{\prime} 53^{\prime \prime}\right) \\
\left.\text { and } 9 \text { (S } 24^{\circ} 42^{\prime} 48^{\prime \prime} \text { and WO } 48^{\circ} 04^{\prime} 52^{\prime \prime}\right)\end{array}$ & $\begin{array}{l}\text { Points with similar environmental characteristics, presenting high densities } \\
\text { of Nymphaea spp., } P \text {.stratiotes, E. azurea and E. crassipes }\end{array}$ \\
\hline $\begin{array}{l}\left.10 \text { (S } 24^{\circ} 42^{\prime} 50^{\prime \prime} \text { and WO } 48^{\circ} 04^{\prime} 52^{\prime \prime}\right) \\
\left.\text { and } 11 \text { (S } 24^{\circ} 42^{\prime} 59^{\prime \prime} \text { and WO } 48^{\circ} 04^{\prime} 41^{\prime \prime}\right)\end{array}$ & $\begin{array}{l}\text { Beginning and ending of the wetland's exit channel, respectively, being } \\
\text { characterized by dominance of } P \text {. stratiotes. The point } 10 \text { was characterized } \\
\text { by the strong smell of sulphidric acid }\left(\mathrm{H}_{2} \mathrm{~S}\right) \text { during all the research. }\end{array}$ \\
\hline
\end{tabular}
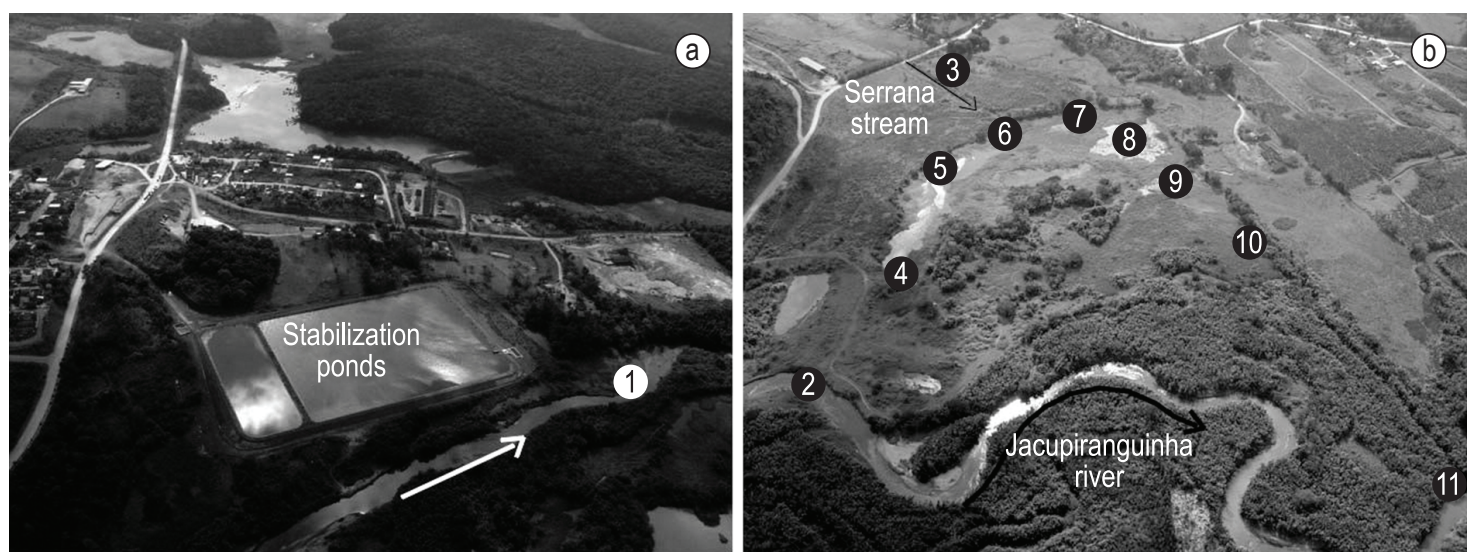

Figure 2. Aerial photography showing the sampling points located at the Jacupiranguinha River ((a) upstream: point 1 and (b) downstream: point 2), (b) within the wetland (points 4 to 10) and at the Serrana stream (point 3).

\subsection{Meteorological and hydrological data}

Data of pluviometric precipitation, air temperature and wind velocity were gathered from an automatic weather station installed at the city of

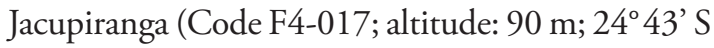
and $\left.48^{\circ} 01^{\prime} \mathrm{W}\right)$.

Recordings of hydrometric levels were obtained from linimetric rulers and automatic linigraphs (T\&S ${ }^{\oplus}$ Model LI3050) installed at the Jacupiranguinha River (automatic stations) and within the wetland (linimetric rulers). Data from automatic linigraphs were gathered hourly and stored in a data logger, while data from linimetric rulers were obtained daily by direct readings. The linimetric stations were installed at previously defined topographic levels.

Water flows were estimated in accordance with methodology proposed by Righetto (1998), using data of water velocity measured at stations 2,3 and 11 .

\subsection{Physical and chemical variables}

Water temperature, dissolved oxygen (DO), $\mathrm{pH}$, electrical conductivity (EC) and redox potential (Eh) were measured using a multiparametric probe (Yellow Spring 556 MPS Multisond). Measurements were performed in regular intervals $(10 \mathrm{~cm})$ along the water column, from subsurface to near bottom sediments. Water samples were manually collected from approximately $40 \mathrm{~cm}$ 
below the water surface. Samples for dissolved nutrients determinations were filtered onto glass fiber filters (Whatman ${ }^{\circledast} \mathrm{GF} / \mathrm{C} 47 \mathrm{~mm}$, Maidstone, $\mathrm{UK}$ ), stored in polyethylene bottles and kept frozen $\left(-4^{\circ} \mathrm{C}\right)$ until analytical routines were performed, in accordance with APHA (1999). Total phosphorus (TP) and total nitrogen (TN) were determined in non-filtered samples according to Mackeret et al. (1978) and Golterman et al. (1978), respectively. Total alkalinity was determined by potentiometric titration following Golterman et al. (1978). Suspended solids (organic and inorganic fractions) were determined by gravimetric method in accordance with APHA (1999).

\subsection{Statistical analysis}

Data corresponding to the dry and rainy periods were submitted to exploratory multivariate techniques in order to test the hypothesis of significant differences among them (MANOVA), to reduce the data dimensionality and verify the associations among the variables (Principal Component Analysis - PCA), and to investigate changes in structure spatial of the sampling points (Cluster analysis). The interpretation of the results from PCA was made by examining the projection of plots of the extracted factors on the factorial plane formed with the statistically significant axes (Legendre and Legendre, 1998). The Cluster analysis was carried out using the UPGMA agglomeration method (unweighted pair group method) and the Euclidian distances as similarity index. Input data for the Cluster analysis corresponded to scores from the PCA. All the statistical analyses were running with the software Statistica ${ }^{\circledR}$ Version 6.0 (Statsoft, 2001).

\section{Results}

Regarding the climatic characteristics, the study area presented a well-marked seasonality, represented by a rainy summer and a dry winter. The most part of precipitation was concentrated during the first semester, with the greatest monthly totals recorded in January/05 $(377.0 \mathrm{~mm})$ and March/05 (348.7 mm). Amongst the sampled months, April/05 presented the lowest monthly total $(99.1 \mathrm{~m})$, while October/04 and July/05, months representative of the dry period, presented values of 113.1 and $141.5 \mathrm{~mm}$, respectively. In January/05, the month corresponding to the highest total precipitation, a mean river discharge of 54.300 $\mathrm{m}^{3} . \mathrm{s}^{-1}$ was registered, while for April/05, this value was $8.200 \mathrm{~m}^{3} \cdot \mathrm{s}^{-1}$. Considering the available data, there was a significant correlation between the river's discharges and the corresponding values of precipitation (r-Pearson: 0.51; $\mathrm{p}<0.05 ; \mathrm{n}$ : 156).

The Figure 3 shows daily Jacupiranginha River levels during the research. In general, the values presented a great variability, characterizing an irregular hydrological regimen. By analyzing topographic profiles of the study area, river's hydrometric levels and in situ observations, we could follow the space-temporal dynamics of the connectivity between the Jacupiranguinha River and the wetland. At the hydrometric level of $2.474 \mathrm{~m}$, the wetland felt the first inflows from the Jacupiranguinha River at point 4, while at the $2.975 \mathrm{~m}$ a total connectivity among the systems was observed. Figure 4 shows the evolution of the degree of connectivity between the Jacupiranguinha River and the wetland as a function of the variations in river's hydrometric levels in January, the month in which a complete connectivity was observed (Phase 2). As observed for river discharges, the hydrometric levels presented a significant correlation with those of precipitation (r-Pearson: 0.55; $\mathrm{p}<0.05 ; \mathrm{n}$ : 156).

The $\mathrm{pH}$ values were in the neutral-alkaline range, varying from 6.4 to 9.7 . In general, the highest values were recorded during dry period, with July/05 presenting the greatest monthly mean (8.5; Figure 5a). In April/05, a month corresponding to the rainy period, the values were between 6.4 and 7.4. Spatially, the horizontal gradients were discreet, with values slightly higher at the point 10 . A similar tendency was observed along the vertical profiles, which showed a gentle variation, even when well-developed oxyclines were detected. The points located at the Jacupiranguinha River (points 1 and 2) and at the Serrana stream (point 3) presented $\mathrm{pH}$ values of comparable magnitude with those within the wetland.

Throughout the study period, the points in the wetland presented values of DO below $2.0 \mathrm{mgO}_{2} \cdot \mathrm{L}^{-1}$. In October/04 (dry period), the values varied from 0.46 (point 6) to $1.78 \mathrm{mgO}_{2} \cdot \mathrm{L}^{-1}$ (point 8), while in January/05 (rainy period), these ones varied from 0.34 to $1.46 \mathrm{mgO}_{2} \cdot \mathrm{L}^{-1}$. In contrast, the points in the Jacupiranguinha River and Serrana stream presented more oxygenated waters. Point 1 presented the highest values during the research, with a maximum of $6.8 \mathrm{mgO}_{2} \cdot \mathrm{L}^{-1}$ in January/05 (Figure 5b). Point 2, also located at the Jacupiranguinha River, presented well oxygenated waters, particularly in October/04 and January/05. Within the wetland, a tendency of decreasing in DO concentrations from the point 4 to the point 9 was 


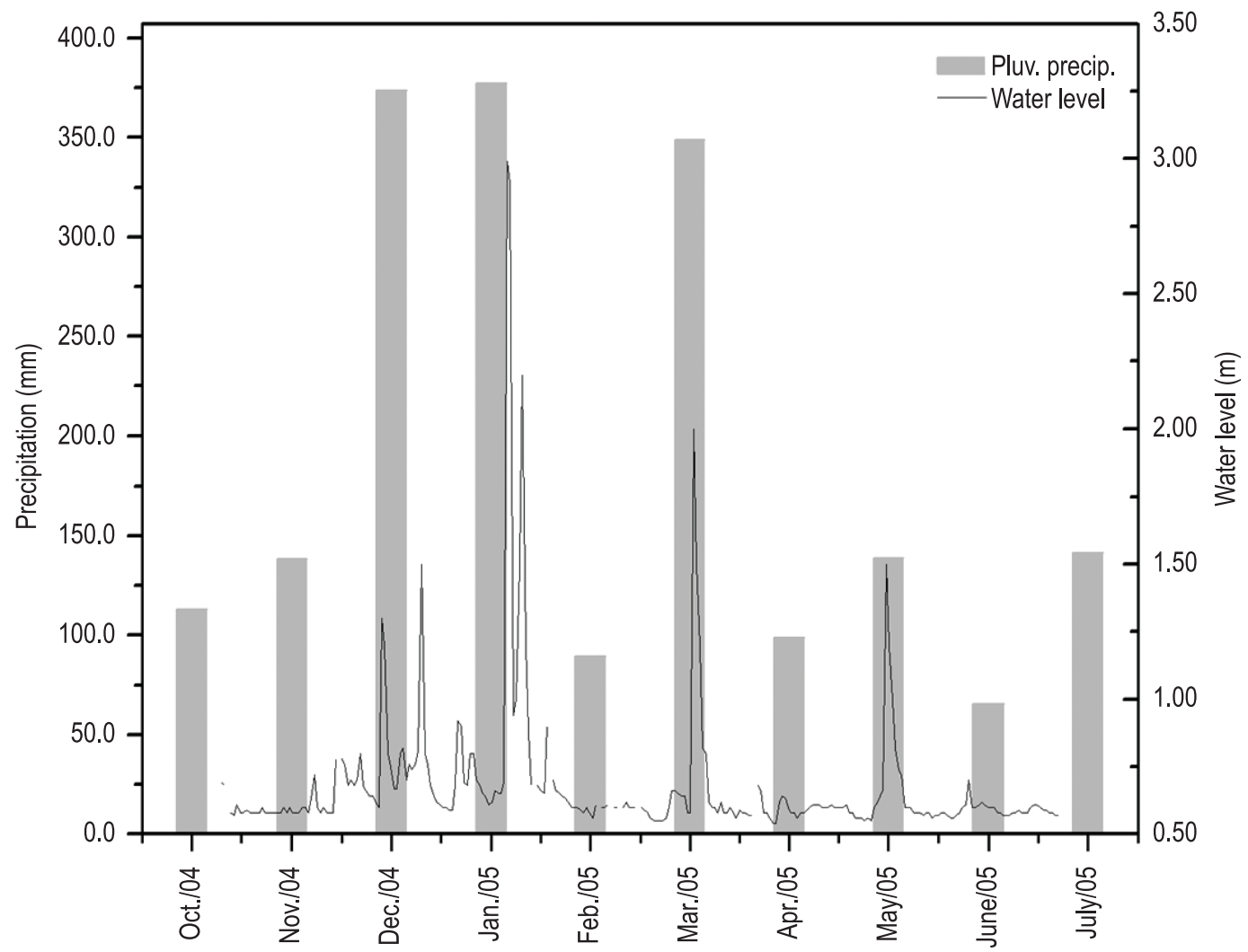

Figure 3. Daily water levels of the Jacupiranguinha River and monthly total of pluviometric precipitation (mm) at the wetland's catchment area during the research.

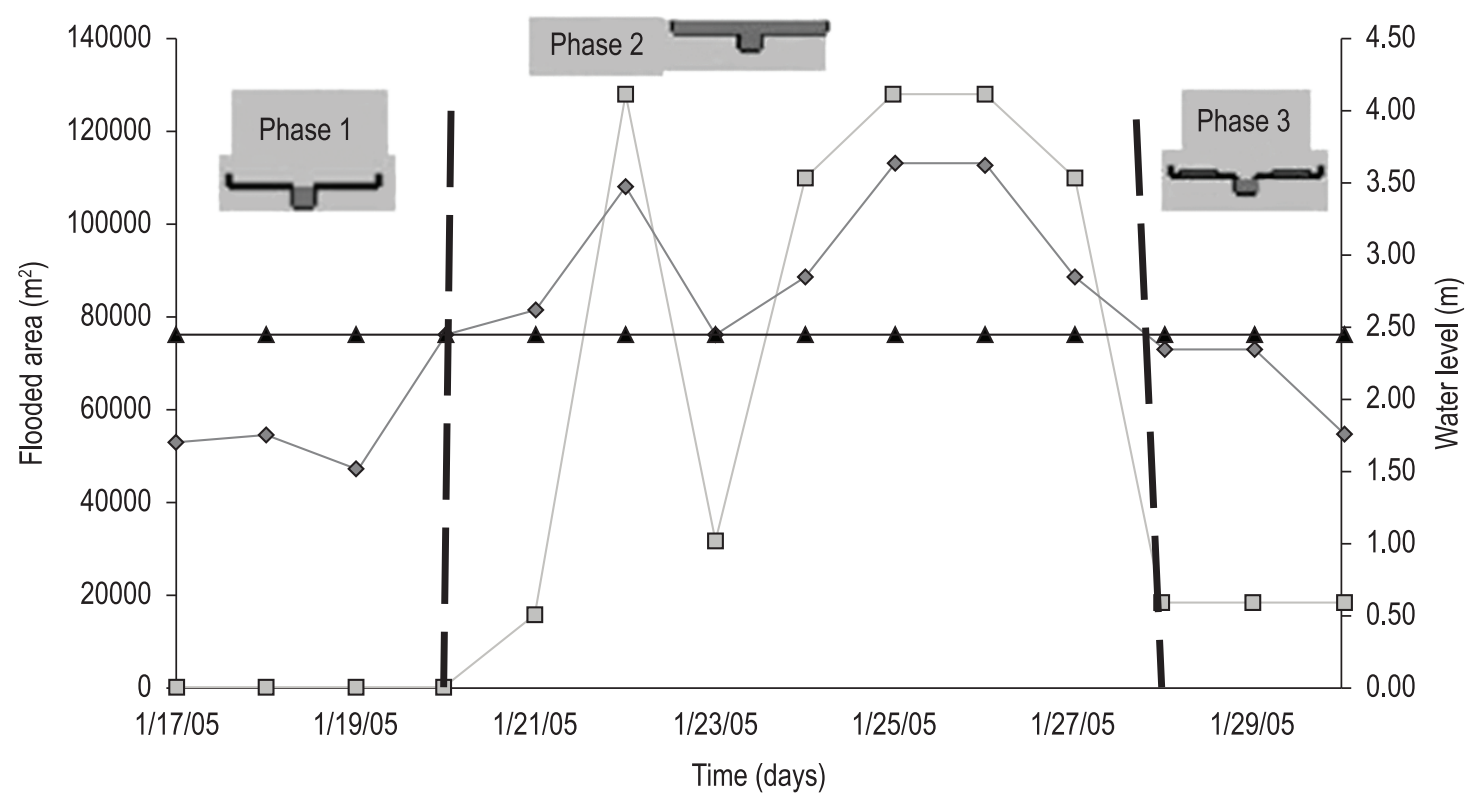

Flooded area $\diamond$ Hydrometric level $\rightarrow$ Overflowing level

Figure 4. Evolution of the degree of connectivity between the Jacupiranguinha River and the wetland in function of the variations in river's hydrometric levels in January. The Phase 2 represents the period of the complete connectivity among the systems during the research (adapted from Almeida-Neto and Mendiondo, 2009). 
observed during the dry period, when the wetland received only minor superficial inflows from Serrana stream. The vertical profiles of DO were well representative of general conditions of oxygenation at the wetland, with well-shaped oxyclines and values towards to zero near the sediment.

In general, the values of the redox potential (Eh) were higher at the points outside of the wetland (points 1, 2 and 3). In October/04, these points presented values ranging between 5.2 and $35.6 \mathrm{mV}$, while within the wetland the corresponding ones were between $-23 \mathrm{mV}$ and $-20 \mathrm{mV}$. In January and July/05, the Eh values were more negative, with exception to the point 2 . The point 10 presented the greatest negative values amongst those sampled, reaching more pronounced values in July/05 $(-111.4$ to $-51.30 \mathrm{mV})$. The vertical profiles followed a similar tendency observed to that observed in respect of DO, with well-developed clines and lowest values (more negative) towards the sediment.

Regarding the EC, the point 2 (Jacupiranguinha River) presented the highest values during the research, with a maximum of $960 \mu \mathrm{S} . \mathrm{cm}^{-1}$ in July/05, while the lowest values were registered at points 1 and 3 in January/05 $\left(67 \mu S . \mathrm{cm}^{-1} \mathrm{e}\right.$ $111 \mu \mathrm{S} . \mathrm{cm}^{-1}$, respectively) (Figure 5c). Seasonally, April/05 and July/05 presented the greatest means of EC. Considering the points within the wetland, there were no pronounced horizontal gradients. However, along the vertical dimension some discontinuities were observed, with a tendency of increasing towards the sediments, particularly below the first meter of the water column.

In relation to total alkalinity, the points located at the Jacupiranguinha River presented the lowest values, varying from 30.0 to $48.0 \mathrm{mgCaCO} \cdot \mathrm{L}^{-1}$. Within the wetland, the values were between 60.0 and $95.0 \mathrm{mgCaCO}{ }_{3} \cdot \mathrm{L}^{-1}$. The Serrana stream (point 3) presented values of comparable magnitude with those found at the wetland, varying from 62.0 (January/05) to $105 \mathrm{mgCaCO} \cdot \mathrm{L}^{-1}$ (July/05) (Figure 5d).

In general, concentrations of TSS were higher in October/04 and in January/05 (rainy period) with greater contribution of the inorganic fraction (ISS). Spatially, point 10 presented the highest concentrations, with exception of April/05 when points 4 and 6 presented the highest values of TSS. In October/04 and January/05, points 1 and 2, situated at the Jacupiranguinha River, presented higher concentrations in comparison with the wetland. With respect to the organic fraction, only in April/05 were the contributions of the OSS greater than those of ISS (Figure 6).
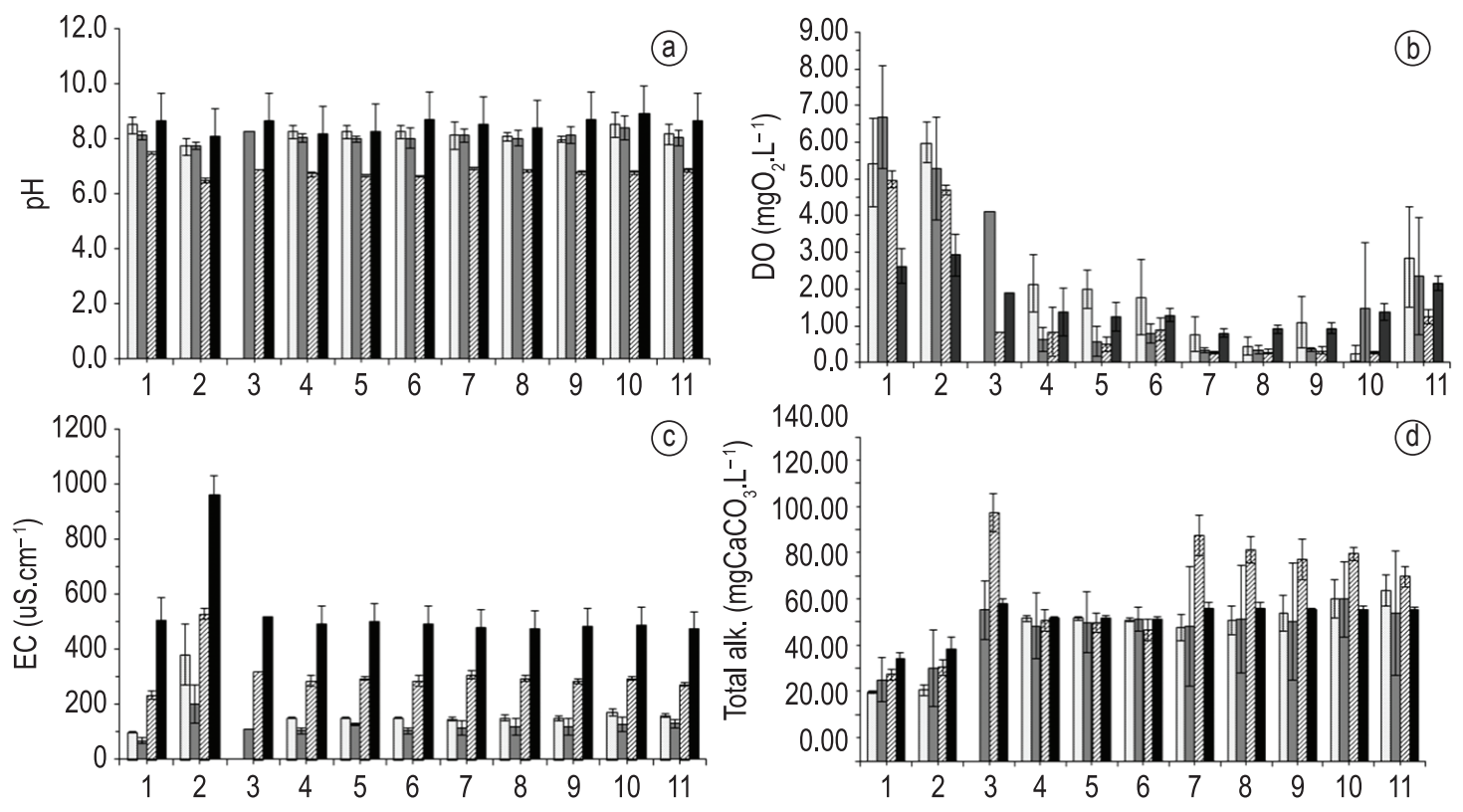

$\square$ Oct./04 \ Jan./05 A Apr./05 July/05

Figure 5. Space-temporal variability of the mean values of (a) pH, (b) dissolved oxygen (DO), (c) electrical conductivity (EC) and (d) total alkalinity. 

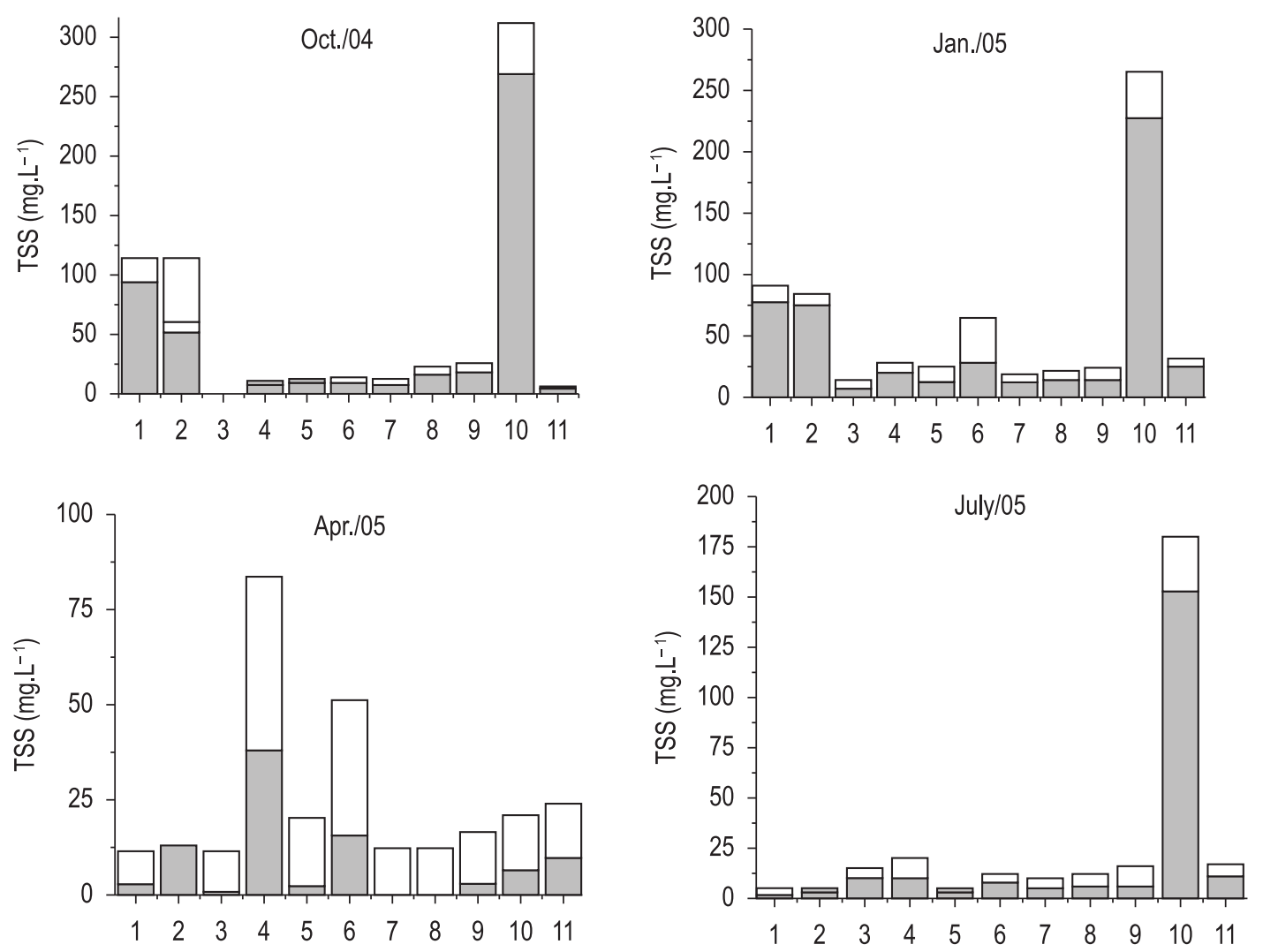

$\square$ ISS $\square$ OSS

Figure 6. Space-temporal variability of the inorganic (ISS) and organic (OSS) suspension solids.

As observed for EC, point 2 presented the highest concentrations of total phosphorus (TP), which reached values as high as $93,566 \mu \mathrm{g} . \mathrm{L}^{-1}$ in July/05. Extremely high concentrations were also recorded in January and April/05: 32,471 g. $\mathrm{L}^{-1}$ and $36,727 \mu \mathrm{g} . \mathrm{L}^{-1}$, respectively. In contrast, point 1 , located upstream, presented the lowest concentrations during the period of study, even when compared to concentrations within the wetland. In general, a tendency of decreasing in TP values from point 4 to point 9 was observed.

As observed with regard to TP, point 2 also presented the highest concentrations of total dissolved phosphorus (TDP), with a maximum value reached in April/05 (36,000 $\left.\mu \mathrm{g} . \mathrm{L}^{-1}\right)$. The lowest concentrations were observed at point 1 and within the wetland. A similar spatial pattern was observed in relation to the soluble reactive phosphorus (SRP). However, in April/05, the highest values of SRP were registered within the wetland, particularly at points 4,5 and 6 , with concentrations varying from $466.0 \mu \mathrm{g} . \mathrm{L}^{-1}$ to 4,414.0 $\mu \mathrm{g} . \mathrm{L}^{-1}$. At this month, point 1 presented concentrations from $33.0 \mu \mathrm{g} . \mathrm{L}^{-1}$ to $99.0 \mu \mathrm{g}$. $\mathrm{L}^{-1}$. In
July/05, points 4, 5 and 6 also presented high SRP concentrations $\left(1,942.0 \mu \mathrm{g} . \mathrm{L}^{-1}-3,164.0 \mu \mathrm{g} . \mathrm{L}^{-1}\right)$, although the maximum was again detected at point $2\left(81,193 \mu \mathrm{g} . \mathrm{L}^{-1}\right)$.

Amongst the forms of dissolved inorganic of nitrogen, the ion nitrate $\left(\mathrm{NO}_{3}^{-}\right)$was the most abundant, reaching the highest concentrations during the rainy period (Figure $7 \mathrm{a}$ ), with January and April/05 presenting mean values of $1.55 \mathrm{mg} . \mathrm{L}^{-1}$ and $1.16 \mathrm{mg} \cdot \mathrm{L}^{-1}$, respectively. Spatially, points 3 (Serrana stream) and 4 presented the greatest concentrations, with maximum values arising in January. Regarding ammoniacal nitrogen $\left(\mathrm{NH}_{3}, 4\right.$, the highest concentrations were observed in October/04 (mean of $2.15 \mathrm{mg} . \mathrm{L}^{-1}$ ), followed by January. Spatially, the points within the wetland presented higher concentrations of $\mathrm{NH}_{3,4}$ in relation to the points at the Jacupiranguinha River (1 and 2) and Serrana stream (point 3; Figure 7b). In relation to total nitrogen ( $\mathrm{TN}$ ), seasonally, as observed for ions nitrate, the highest concentrations were found in January/05 (Figure 7c), when complete connectivity between the wetland and the Jacupiranguinha River took place. For the entire 
duration of the research, and especially at the rainy period, the points within the wetland presented the greatest concentrations of TN, with maximum values registered at points 7 and 9 in January (3.40 and $3.25 \mathrm{mg} . \mathrm{L}^{-1}$, respectively).

The MANOVA Analysis, followed by a hypothesis test to evaluate the seasonality effect on the environmental variables, showed a significant difference between dry and rainy periods (Wilks' Lambda: 0.004), which was confirmed by a Principal Component Analysis (PCA) applied to the same dataset, highlighting two main groups. The two axes extracted from PCA to analysis and interpretation explained $75.67 \%$ of the total data variability (Figure 8 ). Axis I (48.33\%), positively well correlated with TDP, SRF and temperature (Table 2), variables that defined the grouping representative of the dry period, while the Axis II $(27.34 \%)$, positively well correlated inorganic
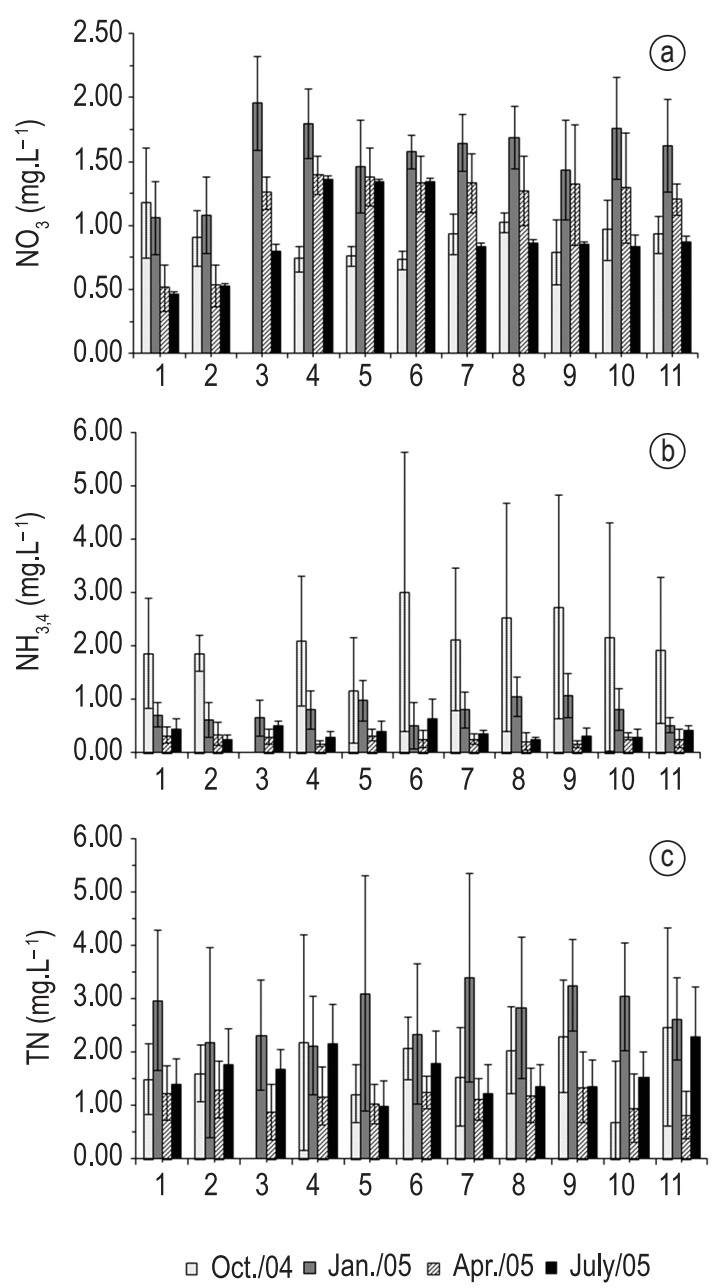

Figure 7. Space-temporal variability of the mean values of (a) nitrate $\left(\mathrm{NO}_{3}^{-}\right)$, (b) ammoniacal nitrogen $\left(\mathrm{NH}_{3,4}\right)$ and (c) total nitrogen (TN). suspended solids (ISS) and total suspended solids (TSS), was considered representative of the rainy.

The Cluster Analysis, considering the points with the wetland ( 4 to 10), gave rise to the formation of four groups: i) two clusters representatives of the dry period (first cluster: points 6, 5 and 4; second cluster: points 7, 8 and 9); ii) one cluster representative of the rainy period (points 4 to 9); and iii) one representative of the point 10 in both periods (Figure 9).

\section{Discussion}

Changes in the hydrological regimen of the Jacupiranguinha River were responsible not only for inducing seasonal variability and nutrient enrichment of the wetland, but also for decreasing its spatial variability during the period of connectivity, as highlighted by the Cluster Analysis (Figure 9). This "homogenization effect" showed the strong influence of hydrological pulses on disrupting the former spatial structure, giving rise to a temporary continuum floodplain river-wetland. Similar results were obtained by Affonso et al. (2011) in floodplain lakes of the Central Amazon (Brazil). These researchers observed the lowest amplitudes for all investigated variables during high water phase, when the lakes were connected with the main channels and rivers, attributing this effect to the huge water volumes received. Other studies carried out in floodplain lakes of the Paraná River and other lakes of the Amazonian region also confirmed the "homogenization effect" brought by periodic floods to the marginal lagoons (Thomaz et al., 1997; Carvalho et al., 2001; Rocha and Thomaz, 2004; Almeida and Melo, 2009).

The flood-pulses are, admittedly, a main factor driving the ecological processes in floodplain wetlands. The inputs of nutrient-rich waters from

Table 2. Pearson's correlation coefficients between abiotic variables and the two first ordination axes extracted from Principal Component Analysis - PCA (*significant correlations; $\mathrm{p}<0.05)$.

\begin{tabular}{|c|c|c|}
\hline \multirow{2}{*}{ Variable } & \multicolumn{2}{|c|}{ Principal component } \\
\hline & Axis 1 & Axis 2 \\
\hline TSS & 0.170 & $0.976^{*}$ \\
\hline ISS & 0.294 & $0.943^{*}$ \\
\hline TDP & $0.742^{*}$ & -0.075 \\
\hline SRP & $0.797^{*}$ & -0.109 \\
\hline $\mathrm{NH}_{3,4}$ & $-0.743^{*}$ & 0.023 \\
\hline Temperature & $0.853^{*}$ & -0.130 \\
\hline $\mathrm{pH}$ & $-0.896^{*}$ & -0.192 \\
\hline Explained variance & $48.33 \%$ & $27.35 \%$ \\
\hline
\end{tabular}




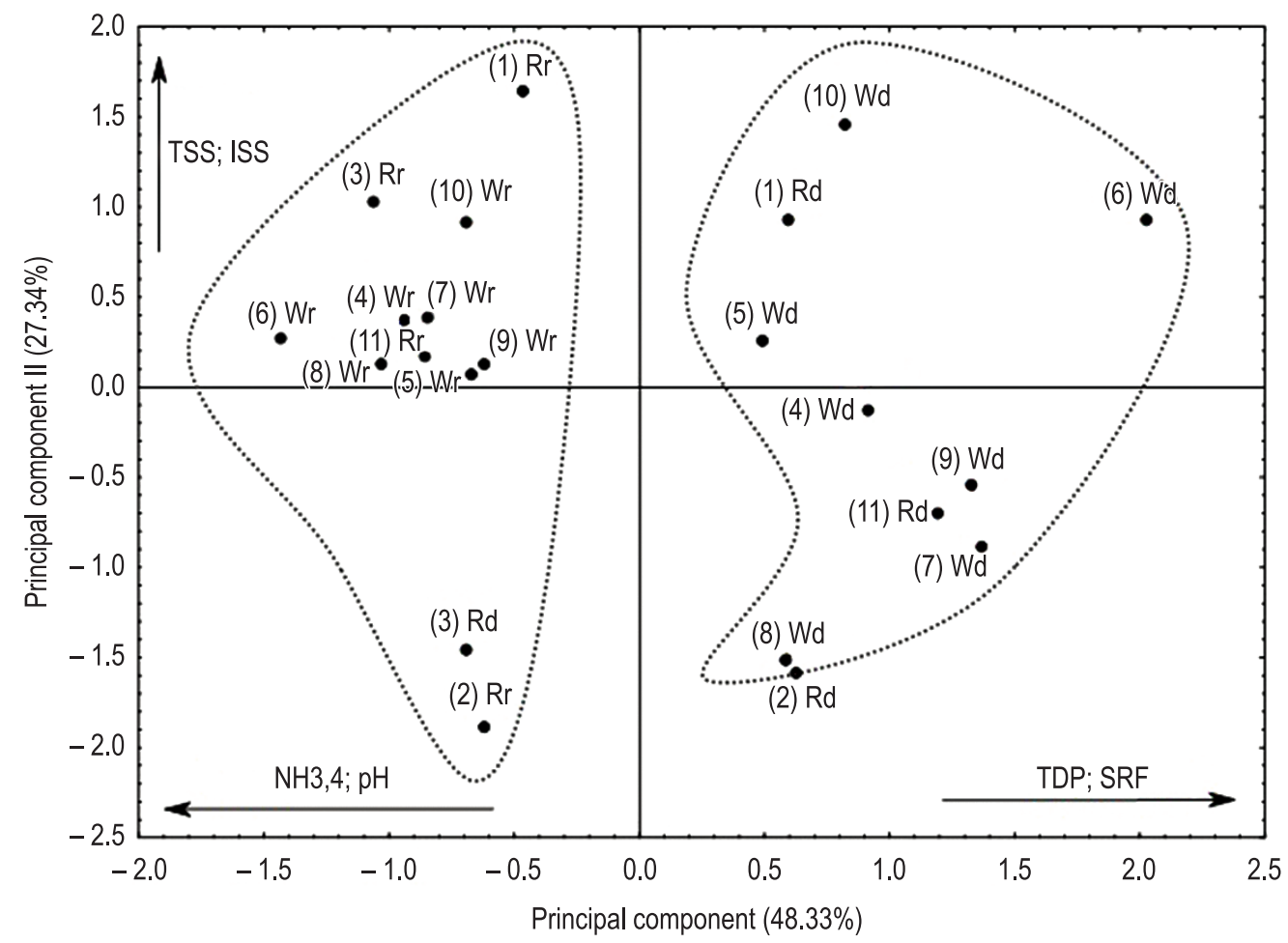

Figure 8. Biplot of a Principal Component Analysis (PCA) showing the two first axes. The point located at the wetland and Jacupiranguinha River were designate by capital letters "W" and "R", while the dry and rainy periods were designated by letters " $\mathrm{d}$ " and " $\mathrm{r}$ ", respectively. By convention, the point situated at the Serrana stream (point 3) was also designated by letter "R".

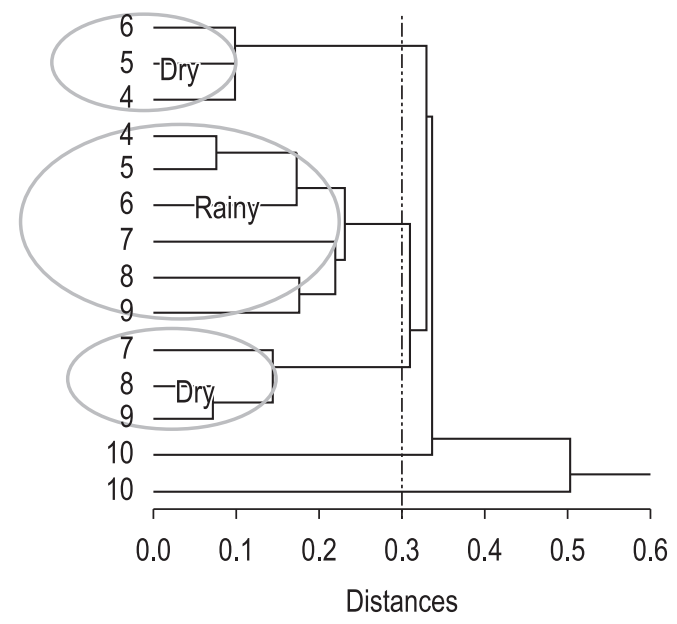

Figure 9. Dendogram showing the main groups resulting from Cluster Analysis using UPGMA as agglomeration method and Euclidian distance as similarity index.

the adjacent rivers during the period of connectivity are usually invoked to explain the high biological productivity of these ecosystems (Junk et al., 1989; Carignan and Neiff, 1992; Junk, 1997). In our research, besides the input of nutrients (phosphorus and nitrogen), the flood pulses were also responsible for suspended material load to the wetland during the high waters period. The load of sediments was mainly represented by the inorganic fraction (ISS), as supported by the PCA results (positive side of the axes II; Figure 8). In comparison with some lotic systems located in the same region, the Jacupiranguinha River presents a high level of human interference. The substitution of the original vegetation on the riversides by banana crop, the direct discharges of treated effluents from a stabilization ponds system (38 L.s $\left.{ }^{-1}\right)$ and of raw effluents from an industrial plant are considered the main impacting activities on the river (Calijuri et al., 2008). Therefore, in addition to the diffuse pollution, represented by the urban and rural runoff, the Jacupiranguinha River presents significant point pollution sources.

The influence of the raw industrial effluents on the river water quality was particularly noticed in terms of the abnormally high concentrations of TP and $\mathrm{EC}$ values at point 2 in comparison with the upstream monitored point (point 1 ), which receives direct discharges from the stabilization ponds system. The exploration of minerals of the apatite group by an industrial complex, although being one 
of the most important activities for maintaining the local economy, may represent a significant source of environment contaminants to the river and, indirectly, to the wetland, including heavy metals, which are potentially toxic and injurious for the aquatic biota.

In spite of allochthonous contributions from the Jacupiranguinha River during the connectivity period, confirming the role of the Floodplain Rivers on the enrichment of adjacent ecosystems (Thomaz et al., 1992; Lopes-Ferreira, 2000; Suzuki and Esteves, 2000), the high concentrations of SRP observed during the dry period are a strong indicative of the importance of internal processes to the availability of nutrients in the wetland. Carignan and Neiff (1992) observed substantial amounts of SRP in floodplain lagoons of the Paraná River (Argentina) during the isolation period, attributing its availability to the presence of high-capacity buffer mechanisms that kept the concentrations unaffected by periods of high and low biological demand, contrasting with what is observed in most freshwater environments.

The anoxic status in the wetland throughout the study period was a strong evidence of the occurrence of high rates of organic matter decomposition. However, the maintenance of high concentrations of SRP during the dry period must be seen not only as a resulted of organic-P mineralization processes, but also due to redox reactions, which provoke changes in physical and chemical conditions in microzones of the sediments, thereby favoring the mobilization and release of phosphorus to the overlaying waters (Stumm and Morgan, 1996; Dodds and Whiles, 2010). Considering the results from PCA, the phosphorus recycling processes during the dry period could be represented by the positive side of the Axes I, which was well correlated with SRP, TDP and water temperature (Figure 8).

The decaying of the macrophytes biomass, in addition to the decomposition of the particulate (detrital) and dissolved organic matter from allochthonous sources, may be considered the main processes in determining the strong OD deficits observed during the whole study in the wetland. Conversely, higher DO concentrations found at the Jacupiranguinha River ratified the importance of the turbulent mixing process in forcing oxygen diffusion in lotic ecosystems (Hauer and Hill, 2007). However, although well shaped oxyclines have been observed, the $\mathrm{pH}$ gradients were gentle, revealing the buffering capacity of the wetland's waters, an effect exerted by the buffer system carbonate-bicarbonate $\left(\mathrm{CO}_{3}{ }^{2-}-\mathrm{HCO}_{3}^{-}\right)$, which drives the variations of $\mathrm{pH}$ by a mechanism of ionic equilibrium, compensating the generation of $\mathrm{H}^{+}$from the decomposition processes (Stumm and Morgan, 1996).

In addition to inputs from Jacupiranguinha River, contributions from Serrana stream, a wetland tributary by the left side (point 3) must be considered as an important source of allochthonous organic matter, since this lotic ecosystem drains an area characterized by not only cropping but also the strong presence of pasturing. Inputs from the Serrana stream assume greater importance during the dry period, when the contributions from the adjacent river can be negligible. Perez and Senna (2000) showed the importance of the nitrogen inputs from the Cafundó stream during the drought to the marginal lagoon to the Mogi-Guaçu River (São Paulo, Brazil), when the contributions due to river overflows were considered null.

The higher concentrations of nitrogen in the wetland compared with those recorded in the Jacupiranguinha River showed the importance of the internal recycling for the nutrients availability and their further assimilation and incorporation to the primary producers biomass. In according to Gopal and Masing (1990) and Mitsch and Gosselink (2000), the lower concentrations of nitrogen usually observed in floodplain rivers in comparison to the adjacent wetlands show the importance of the latter, which act as trap for nutrients.

As observed to SRP, the $\mathrm{NO}_{3}{ }^{-}$and $\mathrm{NH}_{3,4}$ concentrations in the wetland were always above the respective detection limits, even during the dry period, when the macrophytes biomass was virtually great when compared with the period of ingression of rich-nutrient river waters. Neiff and Neiff (1984) observed net increments in macrophytes dry biomass during low water phases in the laguna del Chaco (Argentina), indicating that large external nutrient influxes from the river channel were not necessary to sustain high macrophytes net growth rates. In our study, the high density of floating macrophytes observed during whole study period in the wetland was an indicator that the dissolved inorganic nitrogen may have been originated from the mineralization and nitrification of autochthonous organic- $\mathrm{N}$ or that one from Serrana stream inputs. In accordance with Carignan and Neiff (1992), although the nutrient supply from the river, during floods, has been invoked to explain the high productivity often recorded in floodplain ponds, the flood pulse 
hypothesis (Junk et al., 1989) may not be apply to all the floodplain systems since, in addition to river-derived nutrients, internal mechanisms and other external sources may contribute significantly to the primary productivity.

The results showed that the dynamics of environmental variables in the investigated wetland was closely associated with the flood pulses from the Jacupiranguinha River, which, besides being the main external source of nutrients and sediment to the wetland, were responsible for disrupting the initial physical structure, decreasing the spatial variability of physical and chemical variables. Still in relation to the external contributions, we must highlight the inputs from Serrana stream as an important direct source of nutrients and organic matter to the wetland, although their influence on the environmental variables needs to be further investigated. In contrast, autochthonous processes played a fundamental role in determining the availability of nutrients to the primary producers communities during the low waters period.

The effects of the pollutant loads from the industrial complex on the environmental quality of the Jacupiranguinha River and the wetland must be investigated in details, since the kind of generated effluent represents not only a great source of nutrients, contributing to the eutrophication of the receivers ecosystems, but also a significant source of contaminants associated with the exploited minerals, particularly heavy metals. Therefore, we strongly recommend the inclusion of the sediment and aquatic organisms sampling (both from the Jacupiranguinha and the wetland) in the future researches for investigating and comparing the ecological responses of these systems in face the impacts caused by that point pollution source.

\section{Acknowledgements}

Financial support from the Fundaçáo de Amparo à Pesquisa do Estado de São Paulo (FAPESP; 02/13449-1; 03/03859-0 and 04/02274-1 processes) is gratefully acknowledged. The authors would like also to thank to Universidade Federal do ABC - UFABC (Post-graduation Program in Energy) for the postdoctoral scholarship, to SABESP for the availability of climatic data and to BIOTACE Laboratory (University of São Paulo-USP) and its technical staff for the assistance in laboratory and field works. The English review was performed by Patrick Delage, MotMentum Communications (Montreal), to whom we would like to make special thanks.

\section{References}

AFFONSO, AG., QUEIROZ, HL. and NOVO, EMLM. 2011. Limnological characterization of floodplain lakes in Mamirauá Sustainable Development Reserve (Amazonas State, Brazil). Acta Limnologica Brasiliensia, vol. 23, no. 1, p. 95-108.

ALMEIDA, FF. and MELO, S. 2009. Limnological considerations about Amazonian floodplain lake (Catalão lake - Amazonas States, Brazil). Acta Limnologica Scientiarum. Biological Sciences, vol. 31, no. 4, p. 387-395.

ALMEIDA-NETO, P. and MENDIONDO, EM. 2009. Eco-hidrologia de pulsos sobre várzeas: Conceitos, exemplos e cenários. In CALIJURI, MC., MIWA, ACP. and FALCO, PB. Subsidios para a sustentabilidade dos recursos hídricos: um estudo de caso em sub-bacias do Baixo Ribeira de Iguape, São Paulo, Brasil. São Carlos: EESC/USP. p. 67-86.

American Public Health Association - APHA. 1999. Standard methods for the examination of water and wastewater. 20th ed. Washington. 1268 p.

BENASSI, RF. 2007. Dinâmica espaço-temporal de um sistema de áreas alagadas na planície de inundação do Rio Jacupiranguinha, Vale do Ribeira do Iguape, SP. São Carlos: Escola de Engenharia de São Carlos, Universidade de Sáo Paulo. 191 p. [Tese de Doutorado em Hidráulica e Saneamento].

CALIJURI, MC., CUNHA, DGF., QUEIROZ, LA., MOCCELLIN, J. and MIWA, ACP. 2008. Nutrients and chlorophyll-a concentrations in tropical rivers of Ribeira de Iguape Basin, SP, Brazil. Acta Limnologica Brasiliensia, vol. 20, no. 2, p. 131-138.

CARIGNAN, R. and NEIFF, JJN. 1992. Nutrient dynamics in the floodplain ponds of the Paraná River (Argentina) dominated by the water hyacinth Eichornia crassipes. Biogeochemistry, vol. 17, p. 85-121. http://dx.doi.org/10.1007/BF00002642

CARVALHO, P., BINI, LM., THOMAZ, SM, OLIVEIRA, LG., ROBERTSON, B., TAVECHIO, WLG. and DARWISCH, AJ. 2001. Comparative limnology of South American floodplain lakes and lagoons. Acta Scientiarum. Biological Sciences, vol. 23, no. 2, p. 265-273.

Companhia de Saneamento Básico do Estado de São Paulo - SABESP. 2005. A Sabesp: Sua Região. Available from: <http://www2.sabesp.com.br/ $\mathrm{html} / \mathrm{a} \_s a b e s p / s u a \_r e g i a o / d e t a l h e s . a s p ? i n i c$ mun $=c \&$ municipio $=726 \& x=8 \& y=9>$. Access in: 12 jul. 2011.

DODDS, W. and WHILES, M. 2010. Freshwater Ecology: concepts and environmental applications of limnology. 2nd ed. Elsevier, Inc. 811 p.

GOLTERMAN, HL, CLYNO, RS. and OHNSTAD, MAM. 1978. Methods for physical and chemical analysis of freshwater. 2nd ed. Oxford: Blackwell Scientific Publications. IBP Handbook no. 8. 214 p. 
GOPAL, B. and MASING, V. 1990. Biology and Ecology. In PATTEN, BC., ed. Wetlands and shallow continental water bodies: Natural and human relationships. The Hague: SPB Academic Publishing. vol. 1, p. 91-239.

HAUER, FR. and HILL, WR. 2007. Temperature, Light and Oxygen. In HAUER, FR. and LAMBERTI, GA., eds. Methods in stream ecology. 2nd ed. Elsevier Inc. $895 \mathrm{p}$.

HENRY, R. 2003. Os ecótonos nas interfaces dos ecossistemas aquáticos: conceitos, tipos, processos e importância. Estudo de aplicaçấo em lagoas marginais ao Rio Paranapanema na zona de sua desembocadura na represa de Jurumirim. In HENRY, R., ed. Ecótonos nas interfaces dos ecossistemas aquáticos. São Carlos: Rima Editora. p. 1-28.

JUNK, WJ., BAYLEY, PB. and SPARKS, RE. 1989. The flood pulse concept in river-floodplain systems. In DODGE, DP. (Ed.). Proceedings of the International Large River Symposium (LARS). Canadian Special Publication of Fisheries and Aquatic Sciences, no. 106, p. 110-227.

JUNK, WJ. and WELCOMME, RL. 1990. Floodplains. In PATTEN, BC., ed. Wetlands and shallow continental water bodies. The Hague: SPB Academic. 772 p.

JUNK, WJ. 1997. The Central Amazon Floodplain: Ecology of a Pulsing System. Berlim: Springer-Verlag. 520 p.

KANSIIME, F., KATEYO, E., ORYEM-ORIGA, H. and MUCUNGUZI, P. 2007. Nutrient status and retention in pristine and disturbed wetlands in Uganda: management implications. Wetlands Ecology and Management, vol. 15, no. 6, p. 453-467. http:// dx.doi.org/10.1007/s11273-007-9054-6

LEGENDRE, P. and LEGENDRE, L. 1998. Numerical Ecology. Amsterdam: Elsevier Science V. B. 871 p.

LOPES-FERREIRA, CL. 2000. Estudo de uma área alagada do Rio Atibaia visando à elaboração de proposta de manejo para melhoria da qualidade da água no Reservatório de Salto Grande (Americana, $S P)$. São Carlos: Escola de Engenharia de São Carlos, Universidade de São Paulo. [Tese de Doutorado em Ecologia e Recursos Naturais].

MACKERET, FJH., HERON, J. and TALLING, JF. 1978. Water Analysis: some revised methods for limnologists. London: Freshwater Biological Association Scientific Publication. 121 p.

MITSCH, WJ. and GOSSELINK, JG. 2000. Wetlands. 3rd ed. New York: John Wiley \& Sons. $920 \mathrm{p}$.

MITSCH, WJ., NAHLIK, A., WOLSKI, P., BERNAL, B., ZHANG, L. and RAMBERG, L. 2009. Tropical wetlands: seasonal hydrologic pulsing, carbon sequestration and methane emissions. Wetlands Ecology and Management, vol. 18, no. 5, p. 573-586. http://dx.doi.org/10.1007/s11273-009-9164-4
MOCCELLIN, J. 2006. A microbacia do rio Jacupiranguinha como unidade de estudo para a sustentabilidade dos recursos hidricos do Baixo Ribeira de Iguape - SP. São Carlos: Escola de Engenharia de São Carlos, Universidade de São Paulo. [Dissertação de Mestrado em Hidráulica e Engenharia Sanitária]

NEIFF, JJ. and NEIFF, P. 1984. Cambios estacionales en la biomassa de Eichornia crassipes (Mart.) Solms y su fauna em uma laguna del Chaco (Argentina). Ecosur, vol. 11, p. 51-60.

NEIFF JJ. 1990. Ideas para la interpretación ecológica del Paraná. Interciencia, vol. 15, no. 1, p. 424-441.

NEIFF, JJ. 1999. El régime de pulsos en ríos y grandes humedales de Sudamérica. In MALVAREZ, AI. and KANDUS, P. , eds. Tópicos sobre grandes humedales sudaméricanos. UNESCO. p. 97-145.

NEIFF, JJ. 2001. Diversity in some tropical wetland systems of South America. In GOPAL, B., JUNK, WJ. and DAVIS, JA., eds. Biodiversity in wetlands: assessment, function and conservation. Leiden: Backhuys Publishers. vol. 2, p.157-186.

PEREZ, AC. and SENNA, PAC. 2000. Parâmetros físicos e químicos da Lagoa do Diogo. In SANTOS, JE. and PIRES, JSR., eds. Estação Ecológica de Jataí - estudos integrados em ecossistemas. São Carlos: Rima Editora. vol. 2, p. 377-386.

REBELO, LM., McCARTNEY, MP. and FINLAYSON, CM. 2010. Wetlands of Sub-Saharan Africa: distribution and contribution of agriculture to livelihoods. Wetlands Ecology and Management, vol. 18, no. 5, p. 557-572. http://dx.doi.org/10.1007/ s11273-009-9142-x

RIGHETTO, AM. 1998. Hidrologia e recursos hídricos. São Carlos: EESC/USP. 840 p

ROCHA, RRA. and THOMAZ, SM. 2004. Variação temporal de fatores limnológicos em ambientes da planície de inundação do alto Rio Paraná (PR/ MS - Brasil). Acta Scientiarum. Biological Sciences, vol. 26, no. 3, p. 261-271.

StatSoft. 2001. STATISTICA (data analysis software system). version 6. Available from: <www.statsoft. com>.

SUZUKI, MS. and ESTEVES, FA. 2000. Influence of water level on the dynamics of organic matter, macronutrients and phaeopigments of sediment a tropical lake. Lagoa do Infernão, São Paulo, Brazil. In SANTOS, JE. and PIRES, JSR., eds. Estação Ecológica de Jataí - estudos integrados em ecossistemas. São Carlos: Rima Editora. vol. 2, p. 365-375.

THOMAZ, SM., ROBERTO, MC., LANSACTOHA, FA., LIMA, AF. and ESTEVES, FA. 1992. Características limnológicas de uma estação de amostra do alto Rio Paraná e outra do Baixo Rio Ivinheima - (PR, MS-Brasil). Acta Limnologica Brasiliensia, vol. 4, p. 32-51. 
THOMAZ, SM., ROBERTO, MC. and BINI, LM. 1997. Caracterização limnológica dos ambientes aquáticos e influência dos níveis fluviométricos. In VAZZOLER, AEM., AGOSTINHO, AA. and HAHN, NS., eds. A planície de inundação do alto Rio Paraná: Aspectos físicos, biológicos e socioeconômicos. Maringá: Editora da Universidade Estadual de Maringá. p. 73-102.

TUNDISI, JG. 2007. Exploração do potencial hidrelétrico da Amazônia. Estudos Avançados, vol. 21, no. 59, p. 109-116.
STUMM, W. and MORGAN, JJ. 1996. Aquatic Chemistry: Chemical Equilibria and Rates in Natural Waters. 3rd ed. New York: John Wiley \& Sons, Inc. $1022 \mathrm{p}$.

WHITAKER, VA., MATVIENKO, BA. and TUNDISI, JG. 1995. Spatial heterogeneity of physical and chemical conditions in a tropical reservoir wetland. Lakes \& Reservoirs: Research and Management. vol. 1, p. 169-75. http://dx.doi. org/10.1111/j.1440-1770.1995.tb00019.x

Received: 01 July 2011

Accepted: 05 May 2012 